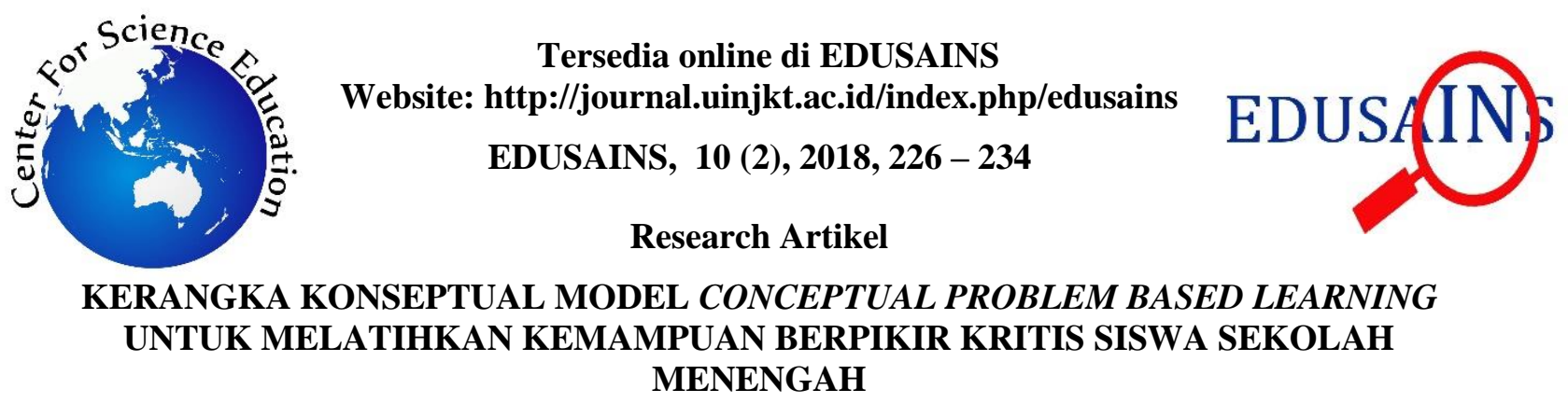

\title{
CONCEPTUAL FRAMEWORK OF CONCEPTUAL PROBLEM BASED LEARNING MODEL TO FACILITATE CRITICAL THINKING SKILLS OF SENIOR HIGH SCHOOL STUDENTS
}

\author{
I Wayan Karmana, Taufik Samsuri \\ IKIP Mataram, Indonesia \\ iwankarmanaweda@gmail.com
}

\begin{abstract}
Learning to facilitate critical thinking requires a set of specific learning models that aims to trains critical thinking skills that in this study is the development of conceptual problem based learning model. This study aims to develop a conceptual problem-based learning model to facilitate high school students' critical thinking skills. This study is a development research that will produce a model of learning products, namely a valid Conceptual Problem Based Learning Model to facilitate high school students' critical thinking skills. Validation of CPBL learning model includes two components namely content validity and construct validity. The result of data analysis shows that the CPBL model can be declared valid with reliability percentage of $97 \%$ (reliable) based on syntax model assessment that is: 1) prior knowledge; 2) organize; 3 ) investigate; 4) analyze; 5) evaluate; to facilitate critical thinking skills.
\end{abstract}

Keywords: Conceptual Problem Based Learning Model; Critical Thinking Skill

\begin{abstract}
Abstrak
Pembelajaran untuk melatihkan berpikir kritis memerlukan satu set model pembelajaran yang spesifik melatihkan kemampuan berpikir kritis yang dalam penelitian ini pengembangan model conceptual problem based learning. Penelitian ini bertujuan untuk mengembangkan model conceptual problem based learning untuk melatihkan kemampuan berpikir kritis siswa sekolah menengah. Penelitian ini merupakan penelitian pengembangan yang akan menghasilkan produk model pembelajaran, yaitu Model Conceptual Problem Based Learning yang valid untuk melatihkan kemampuan berpikir kritis siswa sekolah menengah. Validasi model pembelajaran CPBL meliputi dua komponen yaitu validitas isi (content validity) dan validitas konstruk (construct validity). Hasil analisis data menunjukkan bahwa model CPBL dapat dinyatakan valid dengan persentase reliabilitas sebesar 97\% (reliabel) berdasarkan penilaian sintaks model yaitu: 1) prior knowledge; 2) organize; 3) investigate; 4) analyze; 5) evaluate; untuk melatihkan kemampuan berpikir kritis siswa sekolah menengah.
\end{abstract}

Kata Kunci: Model Conceptual Problem Based Learning; Kemampuan Berpikir Kritis

Permalink/DOI: http://dx.doi.org/10.15408/es.v10i2.7782

\section{PENDAHULUAN}

Salah satu keterampilan esensial yang harus dimiliki pebelajar di abad 21, yaitu keterampilan berpikir kritis (Partnership 21 $1^{\text {st }}$ Century Skills, 2011). Senada dengan hal itu, Wasis (2016) menyatakan bahwa keterampilan berpikir tingkat tinggi salah satu di antaranya, yaitu berpikir kritis sudah selayaknya menjadi fokus pengembangan pembelajaran di Indonesia, karena diyakini potensial menjadikan seseorang memiliki kecakapan hidup, kreasi dan inovasi sehingga mampu menyelesaikan berbagai permasalahan kehidupan yang semakin kompleks di abad 21 .

Produk pembelajaran yang mengarahkan siswa berpikir tingkat tinggi telah diadopsi dan termuat dalam soal-soal TIMSS (Trends in Mathematics and Science Study) dan PISA (Programme for International Student Assessment) (Martin, dkk., 2011). Wasis dkk (2014) telah melakukan studi komparasi soal UN (Ujian 
Nasional), TIMSS dan PISA. Hasil studi menemukan bahwa soal UN lebih mengukur dimensi pengetahuan faktual pada level penerapan, soal TIMSS lebih mengukur dimensi pengetahuan konseptual pada level analisis, dan soal PISA lebih mengukur pengetahuan pada level analisis dan evaluasi. Deskripsi tersebut menunjukkan bahwa pembelajaran tingkat sekolah menengah di Indonesia kurang menekankan ke arah berpikir tingkat tinggi, sehingga begitu dihadapkan pada permasalahan yang membutuhkan keterampilan berpikir tingkat tinggi, siswa sekolah menengah relatif kesulitan. Laporan TIMSS pada tahun 2007 menyatakan bahwa hanya 5\% dari siswa Indonesia yang dapat mengerjakan soal-soal dalam kategori tinggi dan advance, yang memerlukan penalaran (berpikir kritis). Di sisi lain, 78\% siswa Indonesia hanya dapat mengerjakan soal-soal kategori rendah yang memerlukan knowing atau hafalan saja. Sementara Negara-negara Asia seperti Jepang, Korea, Taiwan, Hongkong, Singapura, Malaysia, dan Thailand berada di atas Indonesia (TIMSS, 2007). Selain itu, hasil studi PISA menunjukkan Indonesia peringkat 10 terbawah dari 65 negara. Diketahui juga bahwa siswa Indonesia menguasai pelajaran hanya sampai pada level 3, sementara negara-negara lain ada yang mencapai level 4, 5, dan 6 (PISA, 2009).

Model pembelajaran yang menghadapkan siswa pada permasalahan otentik dan memfasilitasi siswa menyelesaikan permasalahan tersebut, seperti halnya model Problem Based Learning (PBL) berpotensi melatih kemampuan berpikir siswa (Gabr dan Mohamed, 2011; Nugraheni, 2007; Yuan, dkk., 2008). Hal ini diperkuat oleh hasil penelitian Solang (2008) dan Bilgin, dkk (2009), yang menyatakan bahwa siswa yang diajar dengan model PBL memiliki performa berpikir yang lebih tinggi dari yang menggunakan metode konvensional (diskusi informasi). Hasil kajian tersebut menunjukkan ada potensi melatih kemampuan berpikir termasuk berpikir kritis dengan model PBL atau PBM (Pembelajaran Berbasis Masalah). Namun, PBM di samping memiliki kelebihan, juga terdapat kelemahan dan keterbatasan dalam implementasinya, yaitu menurut Sanjaya (2011), jika siswa tidak memahami untuk apa menyelesaikan masalah tersebut, maka mereka tidak mau belajar, Hallinger dan Bridges (2007) menyatakan salah satu karakteristik PBL adalah orientasai pembelajaran terfokus pada masalah otentik yang diberikan dibandingkan disiplin ilmu atau konsep akademik ilmu yang dibelajarkan. Hal tersebut menyebabkan penerapan PBL cenderung tidak dapat mengakomodasi materi yang berkaitan dengan pengetahuan konseptual dan deklaratif, karena pada PBM pembahasan materi sangat tergantung kepada masalah yang dipecahkan, di mana umumnya bersifat pengetahuan kondisional, sehingga masalah yang dipecahkan siswa bisa jadi bersifat kurang representatif, seperti dikatakan Dods dalam Burris dan Bryan (2007), siswa dalam PBM mungkin memiliki pengetahuan yang mendalam tentang materi terkait masalah yang dipecahkan, tetapi tidak representatif dari isi materi pelajaran. Kekurangan-kekurangan inilah yang selanjutnya memunculkan inovasi peneliti mengembangkan model PBM dengan mengintegrasikan kegiatan pengidentifikasian pengetahuan awal siswa (prior knowledge) dan perluasan hasil identifikasi pengetahuan awal dan jangkar pengetahuan menuju materi inti pembelajaran (advance organizer) yang spesifik melatih kemampuan berpikir kritis siswa.

Model CPBL didasarkan pada kelemahankelemahan model PBL menurut beberapa ahli yang menyatakan dalam pembelajaran yang mengimplementasikan model PBL siswa cenderung tidak memahami pengetahuan konsep dan deklaratif (Burris dan Garton, 2007) dan ide bahwa dalam pembelajaran dibutuhkan prior knowledge, advance organizer untuk mengakomodir kelemahan yang disampaikan peneliti maupun ahli sebeumnya. Pengetahuan awal (prior knowledge) merupakan kumpulan pengetahuan dan pengalaman individu yang diperoleh sepanjang hidup mereka dan apa yang Ia bawa kepada pengalaman belajar baru. Suatu pengetahuan awal siswa menentukan kemungkinan-kemungkinan pembelajaran baru, dan apa yang telah diketahui individu sedikit banyak mempengaruhi apa yang mereka akan pelajari (Nur, 2011). 


\section{METODE}

Penelitian ini merupakan penelitian pengembangan yang menghasilkan suatu produk model pembelajaran baru, dalam hal ini yaitu model CPBL. Menurut Nieveen (2007) kerangka suatu produk yang berkualitas meliputi tiga kriteria, yaitu validity, practicality, dan effectiveness.

Pada tahap ini hanya dilakuakan uji validitas model yang dikembangkan. Validitas yang dilakukan memuat unsur content validity pada komponen-komponen penyusun model, di antaranya sintaks (syntax), sistem sosial (social system), prinsip reaksi (principles of reaction), sistem pendukung (support system), dan dampak dari model (effects of the models). Model yang dikembangkan akan divalidasi oleh para pakar dan praktisi. Secara teknis validasi model yang dikembangkan akan dilakukan dalam kegiatan focus group discussion (FGD) yang difasilitasi oleh Pusat Kajian Pendidikan Sains dan Matematika IKIP Mataram (PKPSM IKIP Mataram). Alur pengembangan dan uji validitas model CPBL ditunjukkan pada Gambar 1.

\section{Instrumen Penelitian dan Analisis Data}

Instrumen yang digunakan dalam penelitian ini adalah lembar validasi model pembelajaran. Validasi dimaksudkan untuk memperoleh saran dan masukan dari para validator (pakar dan praktisi), analisis lembar validasi model dilakukan dengan analisis deskriptif. Data hasil dianalisis secara deskriptif kualitatif yaitu dengan membuat rata-rata skor yang diperoleh dari validator. Penilaian terhadap kevalidan model pembelajaran terdiri dari 5 skala penilaian yaitu, sangat kurang $=1$, kurang layak $=2$, cukup layak $=3$, layak $=4$, dan sangat layak $=5$. Skor yang diperoleh dari penilaian ahli, kemudian dikonversikan menjadi data kualitatif skala 5, (Sukardjo, 2005) pada Tabel 1 .

Tabel 1. Kriteria Perangkat Pembelajaran Berdasarkan Rata-rata Nilai Validator

\begin{tabular}{ccc}
\hline No & Interval & Kategori \\
\hline 1. & $\mathrm{Va}>4,21$ & Sangat Valid \\
2. & $3,40<\mathrm{Va} \leq 4,21$ & Valid \\
3. & $2,60<\mathrm{Va} \leq 3,40$ & Cukup Valid \\
4. & $1,79<\mathrm{Va} \leq 2,60$ & Kurang Valid \\
5. & $\mathrm{Va} \leq 1,79$ & Tidak Valid \\
\hline
\end{tabular}

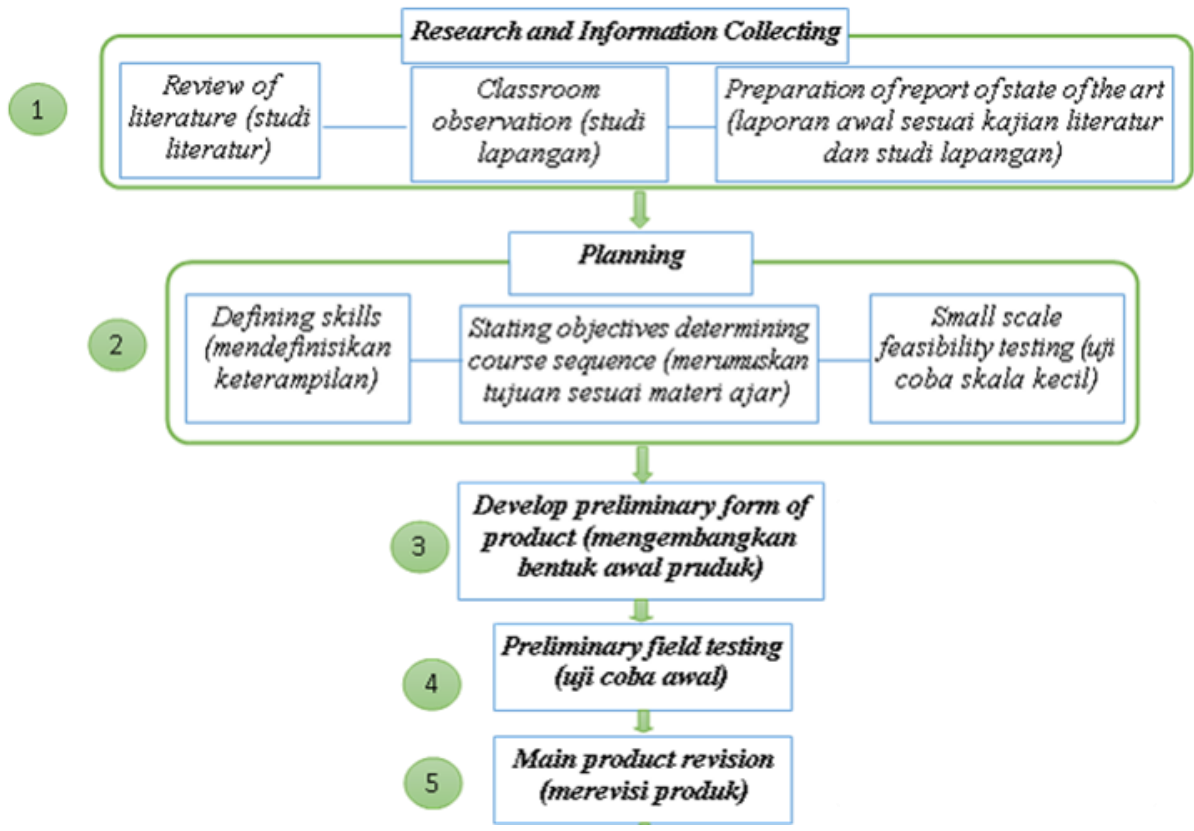

Gambar 1. Alur penelitian pengembangan dan uji validitas model CPBL yang diadaptasi dari Borg dan Gall (1983) dengan pengintegrasian kriteria produk berkualitas oleh Nieveen (2007). 
Rata-rata nilai validasi dan realibilitas model pembelajaran yang dikembangkan ditentukan berdasarkan nilai-nilai yang diberikan oleh validator. Realibilitas model pembelajaran dihitung menggunkan persamaan percentage agreement oleh Emmer dan Millett dalam Borich (1994), instrumen dikatakan realibel jika memiliki percentage agreement sebesar $\geq 75 \%$.

$$
\text { Percentage Agreement }=100\left(1-\frac{A-B}{A+B}\right)
$$

Keterangan:

A $\quad=$ Frekuensi aspek tingkah-laku yang teramati oleh pengamat dengan memberikan frekuensi tinggi.

B = Frekuensi aspek tingkah-laku yang teramati oleh pengamat lain dengan memberikan frekuensi rendah.

\section{HASIL DAN PEMBAHASAN}

\section{Hasil}

$\begin{array}{rccr}\text { Tahap awal yang } & \text { dilakukan setelah } \\ \text { merumuskan } & \text { kerangka hipotetik model }\end{array}$
pembelajaran CPBL adalah validasi produk yang telah dikembangkan. Validasi model pembelajaran CPBL meliputi dua komponen yaitu validitas isi (content validity) dan validitas konstruk (construct validity). Validitas isi meliputi semua komponen yang menyusun model pembelajaran harus didasarkan pada keadaan dari pengetahuan (state of the art knowledgement) komponen yang dinilai dalam validitas isi adalah kebutuhan akan pengembangan model pembelajaran CPBL dan desain model berdasarkan pengetahuan mutakhir yang secara umum berkategori valid. Hasil penilaian ini berdasarkan tujuan pengembangan model CPBL untuk meningkatkan kemampuan berpikir kritis siswa sebagai kebutuhan akan kompetensi lulusan utama akan keterampilan abad 21 dan tuntutan kurikulum sekolah yang berlaku. Hasil validasi model CPBL disajikan pada Tabel 2.

Tabel 2 menunjukkan bahwa model CPBL dapat dinyatakan valid dengan persentase reliabilitas sebesar $97 \%$ (reliabel). Data-data kevalidan model juga dideskripsikan pada Gambar 2.

Gambar 2 memberikan informasi bahwa model pembelajaran CPBL memiliki potensi yang sangat kuat dalam memfasilitasi siswa menumbuhkembangkan keterampilan berpikir kritis siswa serta sesuai dengan tuntuan keterampilan abad 21 seperti diamanatkan Permendiknas (2015).

\section{Pembahasan}

Hasil analisis data hasil validasi model oleh ahli yang berkompeten dapat disimpulkan bahwa model pembelajaran yang dikembangkan adalah valid dengan beberapa revisi. Skor validitas isi dan konstruk model pembelajaran dari 5 orang validator sebesar 4,2 dengan kategori valid dengan konsistensi penilaian keempat validator dalam kategori reliabel (97\%). Hasil validasi ini didapatkan melalui mekanisme Focus Group Discussion (FGD) yang merupakan suatu diskusi terarah yang bertujuan untuk mendapatkan informasi tertentu yang bersifat spesifik.

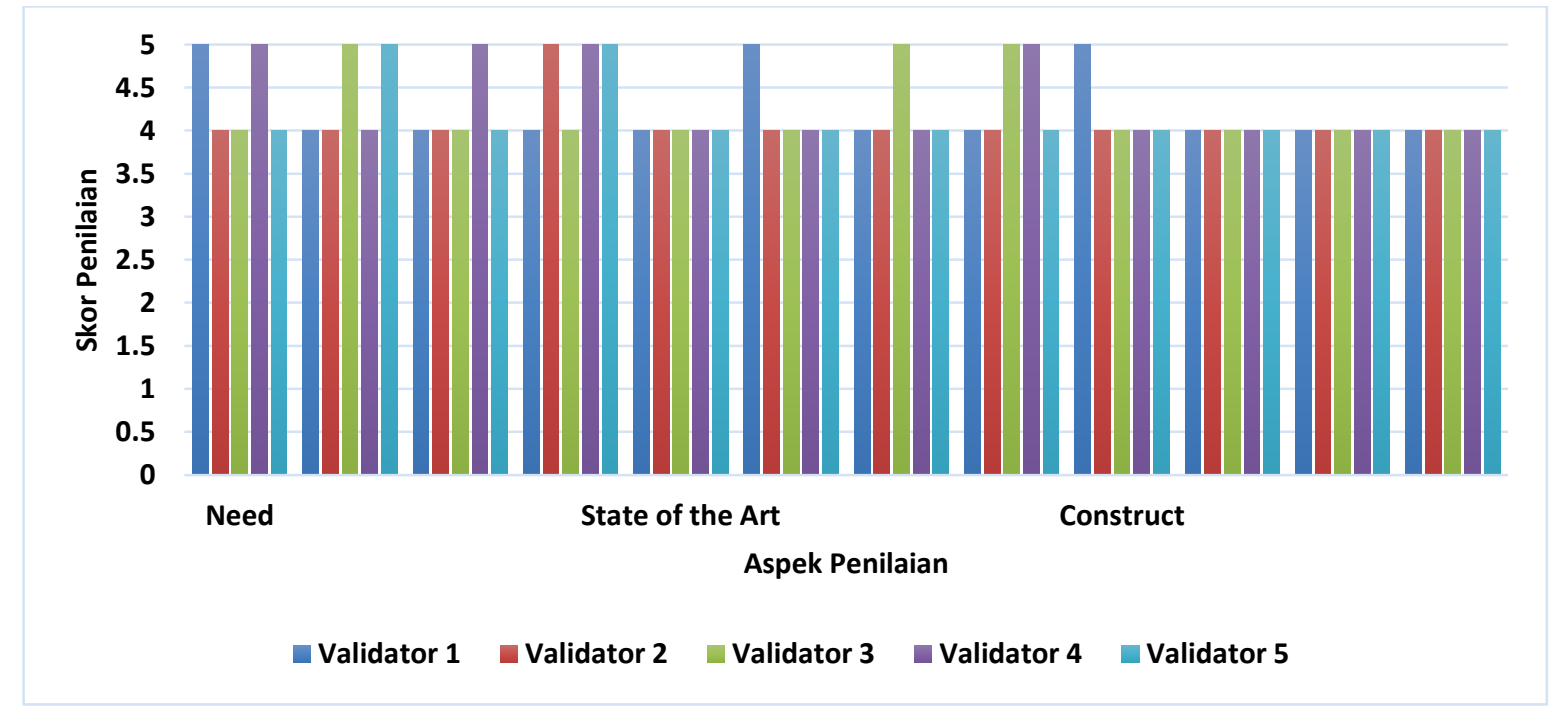

Gambar 2. Kevalidan model CPBL ditinjau dari tiga komponen penilaian 
Proses pengembangan model pembelajran CPBL mengikuti alur penelitian pengembangan Borg dan Gall (1983) dan pengintegrasian karakteristik produk yang berkualitas menurut Nieveen (2007; 1999). Model ini dirumuskan berdasarkan studi pendahuluan dan kajian teoritis sehingga unsur kebutuhan dan kemutakhiran yang menjadi komponen penting dalam validitas isi produk berkualitas dapat terpenuhi, sedangkan konsistensi komponen-komponen penyusun model pembelajaran yang dikembangkan seperti: rasional teoritis, tujuan dan dampak, lingkungan belajar dan sistem sosial, prinsip reaksi, serta sistem pendukung.

Proses pembelajaran pada dasarnya memiliki basis saintifik, proses ini dalam kegiatan praktis menekankan pada pengamatan pada fakta-fakta yang erat dengan lingkungan (Arends, 2012). Pendapat tersebut sesuai dengan komponenkomponen konstruksi model pembelajaran terkait prinsip reaksi dalam model pembelajaran reflektifmetakognitif yang telah dikembangkan. Tujuan pengembangan model pembelajaran ini juga sesuai dengan tuntutan saat ini (need) yang menurut National Research Council of The National Academies (2010) dalam workshop pendidikan sains dan pengembangan keterampilan abad 21 menganjurkan agar dalam pembelajaran, siswa lebih ditekankan pada pembelajaran keterampilanketerampilan abad 21 seperti: 1) kemampuan beradaptasi atau penyesuaian diri dengan lingkungannya, 2) keterampilan berkomunikasi, 3) kemampuan menyelesaikan permasalahan yang tidak rutin ditemukan siswa, 4) manajemen diri/pengembangan diri, dan 5) sistem berpikir. Keterampilan-keterampilan tersebut perlu dibelajarkan untuk menghadapi tuntutan global saat ini. Lebih lanjut Kemendikbud (2012) menekankan agar dalam pembelajaran siswa ditekankan untuk melatih kemampuan (1) memahami informasi yang komplek, (2) teori, analisis dan penyelesaian masalah, (3) pemakaian alat, prosedur dan penyelesaian masalah dan (4) melakukan investigasi. Senada dengan pendapat tersebut Nieveen (2010) menyatakan bahwa dalam penyusunan produk yang berkualitas harus memperhatikan unsur need (kebutuhan terkini) dan state of the art (kesesuaian akan teori dan keterkaitan antar semua komponen penyusun produk yang disusun). Komponen-komponen yang telah diuraikan tersebut telah dipenuhi oleh model pembelajran reflektif-metakognitif yang telah dikembangkan.

Pengembangan model PBL menjadi CPBL didasarkan pada kelemahan-kelemahan model PBL menurut beberapa ahli yang menyatakan dalam pembelajaran yang mengimplementasikan model PBL siswa cenderung tidak memahami pengetahuan konsep dan deklaratif (Burris dan Garton, 2007) dan ide bahwa dalam pembelajaran dibutuhkan prior knowledge, advance organizer untuk mengakomodir kelemahan yang disampaikan peneliti maupun ahli sebeumnya. Pengetahuan awal (prior knowledge) merupakan kumpulan pengetahuan dan pengalaman individu yang diperoleh sepanjang hidup mereka dan apa yang Ia bawa kepada pengalaman belajar baru. Suatu pengetahuan awal siswa menentukan kemungkinankemungkinan pembelajaran baru, dan apa yang telah diketahui individu sedikit banyak mempengaruhi apa yang mereka akan pelajari (Nur, 2011). Konsep yang abstrak dan sulit untuk dipahami terkadang terstuktur dalam pikiran siswa dengan cara yang berbeda-beda berdasarkan apa yang menjadi tujuan mereka. Banyak penelitian terdahulu menunjukkan bahwa siswa mengembangkan kepercayaan dan ide mereka dalam konsep pasti dan fenomena yang ditemui menjadi pengetahuan awal dan membawa pengetahuan tersebut ke dalam kelas (Amir dan Tamir dalam Baryak, 2013). Arends (2012) menyatakan bahwa dalam menghadapi masalah yang membingungkan, individu akan berusaha menghubungkan pengetahuan baru dengan pengalaman sebelumnya (prior knowledge) dan mengkonstruksi makna baru. Bahkan secara lebih jelas dikatakan banyak sedikitnya pengetahuan awal yang dimiliki siswa menentukan efektivitas dalam merancang strategi pemecahan masalah (Eggen dan Kauchak, 2012). Untuk membelajarkan pemahaman konsep pada siswa, dalam sintak pertama, siswa diberikan atau difasilitasi dalam mendefinisikan dan mengklasifikasi istilah dalam konsep-konsep penting dalam materi ajar yang 
disampaikan. Uraian tersebut menunjukkan bahwa prior knowledge merupakan komponen penting dan harus diperhatikan dalam proses pembelajaran. Ausubel dalam Woolfolk (2009), menguatkan bahwa faktor paling penting yang mempengaruhi pembelajaran bermakna adalah tingkat struktur kognitif awal yang telah dimiliki siswa pada saat pembelajaran berlangsung dan dapat digali menggunakan prior knowledge.

Selain prior knowledge, dalam pembelajaran juga dibutuhkan advance organizer, yang menekankan akan pemahaman dan penguasaan konsep dari materi atau topik yang dipelajari oleh peserta didik (Ausubel dalam Woolfolk, 2009). Advance organizer (pengorganisasian awal) ini merupakan alat pengajaran yang direkomendasikan Ausubel untuk mengkaitkan bahan-bahan pembelajaran baru dengan pengetahuan awal (Nur, 2011). Pemberian contoh untuk mengilustrasikan ciri ataupun atribusi kunci serta pemberian contoh tambahan terkait konsep-konsep penting yang terdapat dalam materi yang akan dibelajarkan juga diintegrasikan pada sintak advance organizer dalam model pembelajaran yang dikembangkan.

Adapun kerangka hipotetik fase-fase (langkah) dari model CPBL tertera pada Tabel 3.

Berpikir kritis telah lama menjadi tujuan pendidikan, berpikir kritis dapat membelajarkan siswa untuk membuat perencanaan yang baik, meningkatkan unjuk kerja siswa, serta berpotensi dalam mempersiapkan siswa yang sukses di kehidupan nyata (Dunn et al., 2008). Partnership for $21^{\text {st }}$ century skill (2011) menyertakan keterampilan berpikir kritis sebagai salah satu keterampilan esensial untuk dibelajarkan pada siswa. Pengembangan model CPBL bertujuan untuk melatihkan keterampilan berpikir kritis siswa sekolah menengah. Keterampilan berpikir kritis merupakan kesadaran siswa akan apa yang dipikirkan, dipercaya, diopinikan, serta menyampaikan hal tersebut secara rasional (Ennis, 2011) yang ditunjukkan melalui mengamati, bertanya, dan mencari solusi pemecahan masalah yang dihadapi (Facione, 2011).

Paul dan Elder (2008) lebih lanjut mendeskripsikan bahwa berpikir kritis menjadi penting untuk dibelajarkan karena setiap individu berpikir dan kegiatan tersebut merupakan sifal alami manusia, namun seringkali terjadi bias dan terdistorsi dalam proses berpikir seseorang dan berpikir kritis diperlukan untuk mengatasi hal tersebut. Berpikir kritis merupakan seni dalam menganalisis dan mengevaluasi untuk tujuan meningkatkan kualitas berpikir seseorang. Indikator-indikator keterampilan berpikir kritis yang digunakan dalam penelitian ini adalah 6 (enam) indikator keterampilan berpikir kritis hasil konsensus yang dirangkum Facione (2011) yaitu interpretasi, analisis, inferensi, evaluasi, eksplanasi, dan regulasi diri.

Tabel 3. Sintaks Model CPBL

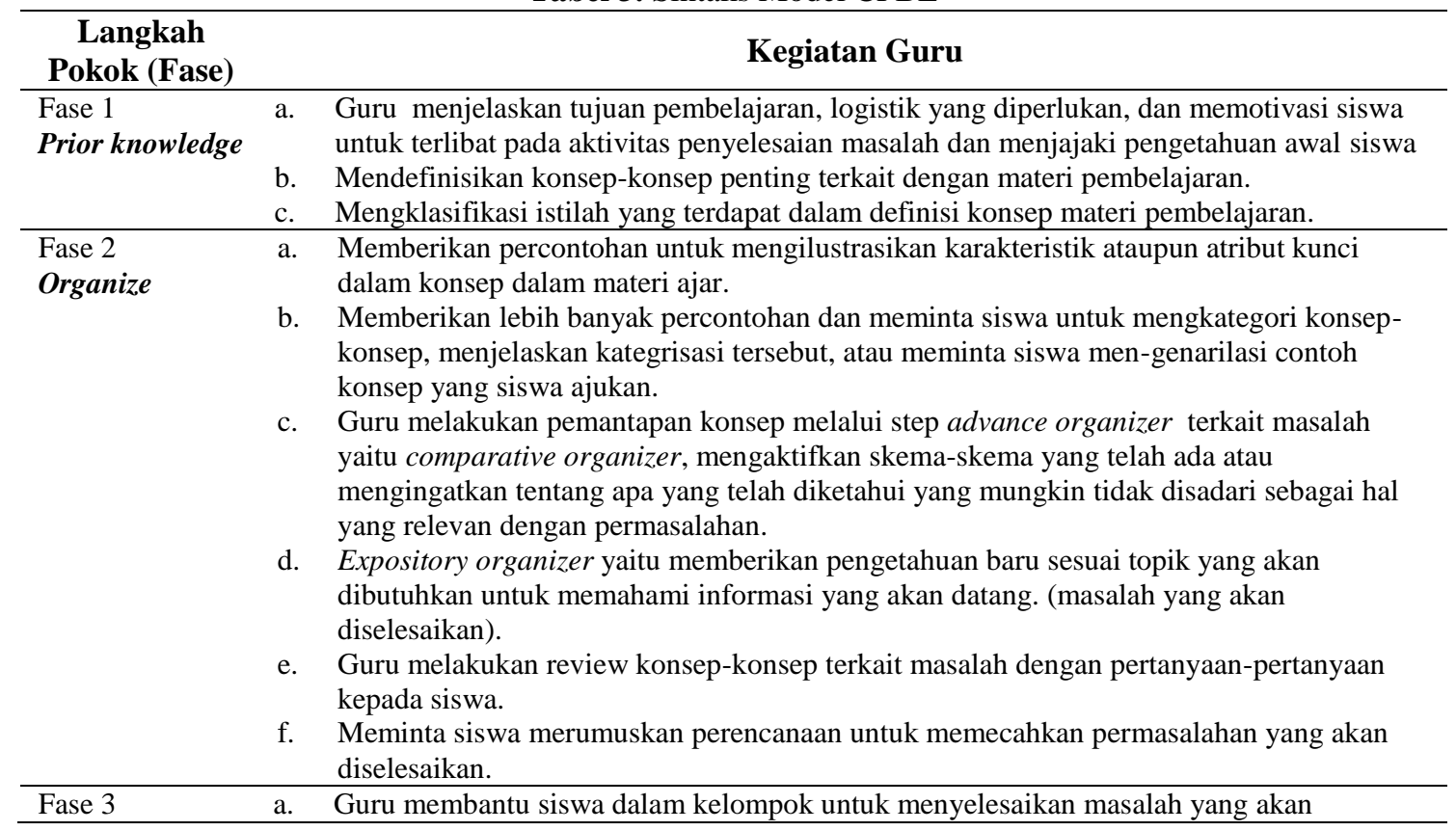




\begin{tabular}{lll}
\hline Investigate & & diselidiki sesuai perencanaan yang tellah disusun. \\
& b. & Mengumpulkan informasi yang sesuai \\
& c. & Melaksanakan eksperimen \\
\hline Fase 4 & a. & Menganalisis hasil investigasi yang telah dilakuakan. \\
Analyze & b. & Mencari penjelasan dan solusi sesuai perencanaan yang telah ditetapkan \\
\hline Fase 5 & a. & Mengevaluasi proses pembelajaran \\
Evaluate & b. & Meminta siswa membuat peta konsep materi yang dipelajari. \\
\hline
\end{tabular}

Tabel 2. Hasil validasi model Conceptual Problem Based Learning (CPBL)

\section{Validitas Isi Model CPBL}

\begin{tabular}{|c|c|c|c|c|c|}
\hline $\begin{array}{l}\text { A. Kebutuhan akan pengembangan Model } \\
\text { Conceptual Problem Based Learning }\end{array}$ & $\begin{array}{c}\text { Validator } \\
1\end{array}$ & $\begin{array}{c}\text { Validator } \\
2 \\
\end{array}$ & $\begin{array}{c}\text { Validator } \\
\mathbf{3} \\
\end{array}$ & $\begin{array}{c}\text { Validator } \\
4 \\
\end{array}$ & $\begin{array}{c}\text { Validator } \\
5\end{array}$ \\
\hline \multicolumn{6}{|l|}{ Aspek yang Dinilai } \\
\hline $\begin{array}{l}\text { a. Pengembangan Model Conceptual Problem Based } \\
\text { Learning bertujuan untuk melatih kemampuan } \\
\text { berpikir kritis siswa sekolah menengah sebagai } \\
\text { kebutuhan akan kompetensi lulusan utama akan } \\
\text { keterampilan abad } 21 \text {. }\end{array}$ & 5 & 4 & 4 & 5 & 4 \\
\hline $\begin{array}{l}\text { b. Pengembangan Model Conceptual Problem Based } \\
\text { Learning bertujuan untuk melatih kemampuan } \\
\text { berpikir kritis siswa sekolah menengah sebagai } \\
\text { tuntutan kebutuhan belajar siswa sebagaimana } \\
\text { tertuang dalam Permendikbud No. } 73 \text { tahun } 2013 \\
\text { tentang Kerangka Kualifikasi Nasional Indonesia } \\
\text { (KKNI) dan Kurikulum 2013. }\end{array}$ & 4 & 4 & 5 & 4 & 5 \\
\hline $\begin{array}{l}\text { c. Kegiatan pembelajaran Model Conceptual Problem } \\
\text { Based Learning direncanakan terlaksananya } \\
\text { kegiatan yang dapat melatih keterampilan proses } \\
\text { ilmiah (saintifik) pada siswa sesuai dengan } \\
\text { Permendikbud No. } 73 \text { tahun } 2013 \text { tentang Kerangka } \\
\text { Kualifikasi Nasional Indonesia (KKNI) dan } \\
\text { Kurikulum } 2013 \text { yang menekankan bahwa proses } \\
\text { pembelajaran menggunakan pendekatan saintifik. }\end{array}$ & 4 & 4 & 4 & 5 & 4 \\
\hline $\begin{array}{l}\text { d. Pengembangan Model Conceptual Problem Based } \\
\text { Learning menjembatani kesenjangan antara harapan } \\
\text { akan kebutuhan kompetensi lulusan abad } 21 \text { yang } \\
\text { kritis dengan kenyataan bahwa kemampuan berpikir } \\
\text { kritis siswa masih tergolong rendah. }\end{array}$ & 4 & 5 & 4 & 5 & 5 \\
\hline Rerata & 4.25 & 4.25 & 4.25 & 4.75 & 4.5 \\
\hline
\end{tabular}

B. Model Conceptual Problem Based Learning didesain berdasarkan pengetahuan mutakhir

\section{Aspek yang Dinilai}

a. Pengembangan Model Conceptual Problem Based Learning mengacu pada teori pembelajaran terkini dari buku mutakhir karangan Woolfolk (2009) dan Arends (2012).

b. Kajian penelitian mengakomodir aspek-aspek berpikir kritis yang telah digalakkan oleh Partnership for 21 st century skills.

c. Pengembangan Model Conceptual Problem Based Learning mengacu pada kajian empiris tentang pemahaman konsep, pembelajaran berbasis masalah dan berpikir kritis dari referensi jurnal internasional.

d. Tujuan pengembangan Model Conceptual Problem Based Learning telah mengacu pada referensi berpikir kritis menurut para pakar yang menjadi acuan peneliti lain di dunia.

Validitas Konstruk Model CPBL

Aspek yang Dinilai

a. Fase-fase Model Conceptual Problem Based Learning menunjukkan proses-proses pemecahan masalah dalam kegiatan proses-proses ilmiah.

b. Fase-fase Model Conceptual Problem Based Learning menunjukkan urutan kegiatan pembelajaran yang logis.

c. Fase-fase Model Conceptual Problem Based Learning saling mendukung dan terkait.

\begin{tabular}{lllll}
4 & 4 & 4 & 4 & 4 \\
5 & 4 & 4 & 4 & 4 \\
4 & 4 & 5 & 4 & 4 \\
4 & 4 & 5 & 5 & 4 \\
\hline 4.25 & 4 & 4.5 & 4.25 & 4 \\
\hline
\end{tabular}


d. Peran pengajar dalam Model Conceptual Problem

Based Learning telah sesuai dengan fase pembelajaran.

\begin{tabular}{ccccccc} 
Remata & 4.25 & 4 & 4 & 4 & 4 \\
\hline Jumlah & 51 & 49 & 51 & 52 & 50 \\
\hline Reliabilitas & \multicolumn{5}{c}{$\mathbf{9 7 \%}$} \\
\hline
\end{tabular}

Paul dan Elder (2008) lebih lanjut mendeskripsikan bahwa berpikir kritis menjadi penting untuk dibelajarkan karena setiap individu berpikir dan kegiatan tersebut merupakan sifal alami manusia, namun seringkali terjadi bias dan terdistorsi dalam proses berpikir seseorang dan berpikir kritis diperlukan untuk mengatasi hal tersebut. Berpikir kritis merupakan seni dalam menganalisis dan mengevaluasi untuk tujuan meningkatkan kualitas berpikir seseorang. Indikator-indikator keterampilan berpikir kritis yang digunakan dalam penelitian ini adalah 6 (enam) indikator keterampilan berpikir kritis hasil konsensus yang dirangkum Facione (2011) yaitu interpretasi, analisis, inferensi, evaluasi, eksplanasi, dan regulasi diri.

\section{PENUTUP}

\section{Kesimpulan}

Berdasarkan hasil penelitian dapat disimpulkan bahwa model conceptual problem based learning dinyatakan valid untuk melatihkan kemampuan berpikir kritis siswa.

\section{Saran}

Hasil analisis data menunjukkan bahwa model CPBL dapat dinyatakan valid, namum perlu beberapa perbaikan seperti konsistensi terkait tujuan yang ingin dicapai yaitu kemampuan berpikir kritis.

\section{DAFTAR PUSTAKA}

Arends, R. 2012. Learning to Teach. Ninth Edition. McGraw-Hill. New York.

Bayrak, B.K. 2013. Using Two-Tier Test to Identify Primary Students' Conceptual Understanding and Alternative Conceptions in Acid Base. Mevlana International Journal of Education (MIJE). 3(2): 19-26.

Bilgin,I., Senocak, E., \& Sozbilir, M. 2009. Effect of Problem- Based Learning Instruction on University Student's Performance of Conceptual and Quantitative Problem in Gas
Concepts. Journal of Mathematics, Science and Tecnology Education. 5(2): 153-164

Burris, S \& Garton, B, L.2007. Effect of Instructional Strategy on Critical Thinking and Content Knowledge: Using ProblemBased Learning in the Secondary Classroom. Journal of Agricultural Education. 48 (1): 106-116

Chi, M. T. H., \& Brem, S. K. (2009). Contrasting Ohlsson's Resubsumption Theory with Chi's Categorical Shift Theory. Educational Psychologist, 44: 58-63.

Destalia, L., Suratno, \& Apriliya, S. 2014. Peningkatan Keterampilan Pemecahan Masalah dan Hasil Belajar Melalui Pembelajaran Berbasis Masalah (PBM) dengan Metode Eksperimen pada Materi Pencemaran Lingkungan. Pancaran, 3 (4): 213-224.

Dunn, D.S., Halonen, J.S., and Smith, R.A. 2008. Engaging Minds: Introducing Best Practices in Teaching Critical Thinking in Psychology. Teaching Critical Thinking in Psychology. Blackwell Publishing Ltd. Chichester.

Duron, H., Limbach B., dan Wough W. 2006. Critical Thinking Framework to Any Dicipline. International Journal of Teaching and Learning in Higher education. Volume 17(2): 160-166.

Eggen, P. \& Kauchak, D. 2012. Strategi dan Model Pembelajaran. Indeks. Jakarta.

Ennis. R.H. 2011. The Nature of Critical Thinking: An Outline of Critical Thinking Dispositions and Abilities. Sixth International Conference on Thinking. MIT, Cambridge, MA, May 2011. Hal. 1-8.

Facione, P. 2011. Critical Thinking. What It Is and Why Its Counts. Measured Reason and The California Academic Press. London. 
Gabr, H \& Mohamed, N. 2011. Effect of ProblemBased Learning on Undergraduate Nursing Students Enrolled In Nursing Administration Course. International Journal of Academic Research. 3(1): 154-162

Hallinger, P dan Bridges, E.M. 2007. A Problembased Approach for Management Education. Springer. Dordrecht.

Ibrahim, M. 2012. Konsep, Miskonsepsi dan Cara Pembelajarannya. Unesa University Press. Surabaya.

Martin, M.O., Mullis, I.V.S., Foy, P., dan Stanco, G.M. (2012). TIMSS 2011 International Results in Science. Boston College, Chestnut Hill: TIMSS \& PIRLS International Study Center.

Nieveen, N. 2007. Formative Evaluation in Educational Design Research. Proceedings of the seminar conducted at the East China Normal University. 23-26 November 2007. Shanghai, PR China. Hal 88-101.

Nugraheni, E. 2007. Student Centered Learning dan Implikasinya terhadap Proses Pembelajaran. Jurnal Pendidikan. 8 (1): 1-10.

Nur, M. 2011. Strategi-strategi Belajar. Pusat Sains dan Matematika Sekolah UNESA. Surabaya.

Partnership for 21st Century Skills. (2011). Framework for 21st Century Learning, www.p21.org.
Paul, R. dan Elder, L. 2008. Critical Thinking (Concepts and Tools). The Foundation for Critical Thinking.

Paul, R., Bingker, A.J.A., Martin, D., Vetrano, C., Kreklau, H. 1989. Critical Thingking Handbook. Central for Critical Thingking and Moral Critique. Rohnert Park.

Sanjaya, 2011. Strategi Pembelajaran Berorientasi Standar Proses Pendidikan. Kencana. Jakarta.

Solang, D. J. 2008. Latihan Keterampilan Intelektual dan Kemampuan Pemecahan Masalah Secara Kreatif. Jurnal Ilmu Pendidikan. 15 (1): 35-42.

Sukarjo. 2005. Evaluasi Pembelajaran. Diktat Mata Kuliah Program Studi Teknologi Pembelajaran. Universitas Negeri Yogyakarta. Tidak diterbitkan

Wasis, Yuni, S.R, dan Sukarmin. (2014). Karakterisasi Instrumen Penilaian Berpikir Tingkat Tinggi dan Literasi Sains: Studi komparatif soal TIMSS, PISA, dan UN. Laporan penelitian fundamental yang didanai oleh DP2M Dikti.

Wasis. 2016. Higher Order Thinking Skills (HOTS): Konsep Dan Implementasinya. Prosiding Seminar Nasional PKPSM. 12 Maret 2016. Mataram, Indonesia. Hal xivxviii.

Woolfolk, A. 2009. Educational Psychology Bagian Kedua Edisi Kesepuluh. Pustaka Pelajar. Yogyakarta. 